\title{
Tingkat Motivasi dan Hubungannya dengan Karakteristik Individu Santri dalam Membudidayakan Black Soldier Fly di Kelompok Santri Tani Milenial Kecamatan Kedungkandang Kota Malang
}

\section{Level of Motivation and Relationship with Individual Characteristics of Santri in Cultivating Black Soldier Fly in the Group of Millennial Farmers Santri District Kedungkandang Malang City}

\author{
F. A. D. Pertiwi ${ }^{1 *}$, S. Likah ${ }^{2}$, dan Sunarto ${ }^{2}$ \\ ${ }^{1}$ Program Studi Penyuluhan Peternakan dan Kesejahteraan Hewan, Polbangtan Malang \\ ${ }^{2}$ Politeknik Pembangunan Pertanian Malang \\ Jalan Dr. Cipto 144 A Bedali, Lawang Malang 65200 Kotak Pos Telepon 0341 - 427772 \\ *Corresponding E-mail: firdaayu804@gmail.com \\ (Diterima:10 Oktober 2020; Disetujui: 24 Januari 2021)
}

\begin{abstract}
ABSTRAK
Tujuan dari penelitian ini adalah menganalisa tingkat motivasi dan hubungannya dengan karakteristik individu santri tani dalam membudidayakan Black Soldier Fly (BSF) sebagai pakan alternatif ayam joper. Metode yang digunakan dalam penelitian ini adalah pendekatan kuantitatif dengan analisis deskriptif inferensial. Populasi pada penelitian ini adalah anggota KSTM di Kecamatan Kedungkandang Kota Malang sebanyak 180 orang. Sampel penelitian ini sebanyak 66 orang ditentukan melalui teknik cluster random sampling atau area sampling dan dihitung berdasarkan rumus slovin. Analisis data menggunakan analisis deskriptif dan regresi linier berganda. Hasil kajian berdasarkan analisis deskriptif yaitu tingkat motivasi anggota KSTM dalam budidaya BSF rata-rata pada tingkat sedang (56,5\%). Tingkat motivasi kelompok santri tani milenial dalam budidaya BSF berdasarkan teori Maslow: kebutuhan fisiologis 24,5\%, kebutuhan rasa aman 21,5\%, kebutuhan sosial 21,1\%, kebutuhan penghargaan 18,2\% dan kebutuhan aktualisasi diri 14,7\%. Hasil analisis regresi linear berganda menyatakan bahwa variabel pendidikan, sifat kosmopolitan dan kepemimpinan partisipatif berpengaruh nyata terhadap motivasi dengan taraf signifikasi $\alpha \leq 0,05$. Sedangkan variabel umur tidak berpengaruh nyata terhadap motivasi dengan taraf signifikasi $\alpha \geq 0,05$.

Kata kunci: karakteristik individu, faktor-faktor, motivasi, Maslow, Black Soldier Fly, KSTM

\section{ABSTRACT}

The purpose of this study is to analyze the level of motivation and its relationship with the individual characteristics of farm santri in cultivating Black Soldier Fly (BSF) as an alternative feed for Joper chickens. The method used in this study is a quantitative approach with a descriptive analysis of inferential. The population in this research is a member of KSTM in the district of Kedungkandang Malang City as many as 180 people. This research sample of 66 people was determined through a random sampling cluster technique or sampling area and computed based on the formula Slovin. Data analysis uses descriptive analysis and multiple linear regression. The results of the study based on descriptive analysis are the motivation level of KSTM members in the cultivation of BSF on average at a moderate level (56.5\%). The motivational level of the millennial farmer santri group in the cultivation of BSF based on Maslow's theory: physiological needs $24.5 \%$, security needs $21.5 \%$, social needs $21.1 \%$, appreciation needs $18.2 \%$, and self-actualization needs $14.7 \%$. The results of multiple linear regression analyses stated that educational variables, cosmopolitan properties, and participatory leadership have a real impact on motivation with a significant degree of $\alpha \leq 0.05$. In comparison, the age variable has no real effect on motivation, with the significance of $\alpha \geq 0.05$.
\end{abstract}

Keywords: individual characteristics, factors, motivation, Maslow, Black Soldier Fly, KSTM 


\section{PENDAHULUAN}

Pembangunan sumber daya manusia merupakan fokus utama kementerian pertanian saat ini, diupayakan untuk meningkatkan kualitas masyarakat Indonesia dalam mewujudkan kesejahteraan hidup. Salah satu pembangunan SDM yang sedang digalakan yaitu pemberdayaan santi tani dalam program Kelompok Santri Tani Milenial (KSTM) menuju lumbung pangan dunia 2045. Pondok pesantren merupakan pusat pembelajaran bagi generasi muda di Indonesia sejak dahulu. Kemenag (2019) menyatakan 4.173.421 orang santri tersebar di seluruh Indonesia. Santri di Jawa Timur berjumlah 654.404 orang yang merupakan $1,02 \%$ pemuda produktif yang dimiliki Indonesia (BPS, 2019). Jumlah tersebut merupakan potensi yang besar bagi pembangunan SDM pertanian untuk dicetak sebagai agrointerpreneur melalui program KSTM.

Kota Malang merupakan salah satu wilayah di Jawa Timur yang mendapatkan program bantuan KSTM. Total pesantren di Kota Malang sendiri baik Salafiyah, Ashriyah, atau kombinasi yaitu 55 pondok pesantren. Berdasarkan seleksi yang dilakukan oleh Politeknik Pembangunan Pertanian (Polbangtan) Malang, hanya 6 pondok pesantren yang terpilih dan dipercaya untuk menjalankan program bantuan KSTM. Berikut merupakan 6 pondok pesantren di Wilayah Kota Malang: Darussalam Agung, Al-Hayatul Islamiyah, Darussalam, Nurul Muttaqin Al Barokah, Baitul Makmur, dan Miftahul Ulum.

Program KSTM sudah berjalan pada bulan April tahun 2019, dalam pelaksanaannya dilakukan pendampingan oleh pihak Polbangtan Malang yang bekerjasama dengan dinas pertanian Kota Malang. Permasalahan yang terjadi pada proses budidaya ayam joper yaitu ketersediaan pakan kurang dan harga pakan pabrik yang tinggi. Harga pakan ternak di area Kecamatan Kedungkandang berkisar antara Rp. 350.000 - Rp. 380.000 per sak. Menurut Katayane et al. (2014) komponen terbesar yang mempengaruhi keberhasilan dalam kegiatan usaha peternakan ialah pakan ternak (50-70\%). Hampir semua bahan pakan unggas masih impor diantaranya tepung ikan, bungkil kedelai, leguminosa dan tepung darah. Oleh karena itu, perlu dilakukan upaya untuk mencari sumber protein alternatif yang harganya lebih murah, salah satunya bisa menggunakan larva maggot.

Black Soldier Fly (BSF) di Indonesia sering disebut maggot adalah salah satu insekta yang merupakan sumber protein tinggi asal hewani. Berdasarkan hasil proksimat maggot yang telah dilakukan Azir et al. (2017), menyatakan bahwa maggot yang dikultur dengan menggunakan limbah ikan $50 \%$ dan dedak $50 \%$ memiliki kandungan protein 41,22\%. Menurut Van-Huis (2013) peternak bisa menggunakan insekta untuk menggantikan bahan protein yang harganya semakin mahal karena lebih mudah diperoleh dan ekonomis. Pada budidaya insekta dapat mencegah pencemaran lingkungan dengan menguraikan limbah organik menjadi media tumbuh sekaligus pakan dari insekta. Keuntungan lain dari penggunaan sumber protein berbasis insekta ialah tidak berkompetisi dengan manusia (Veldkamp et al., 2012). Maggot dapat dimanfaatkan sebagai sumber protein pada pakan ternak, serta membantu pada penguraian limbah organik dari pondok maupun dari pasar tradisional di sekitar lokasi KSTM.

Pada pendampingan anggota KSTM sebelumnya telah diperkenalkan mengenai budidaya maggot, tetapi belum ditindaklanjuti dengan pembinaan yang lebih instensif. Perlu diperkenalkan kembali sumber protein dari larva maggot kepada anggota KSTM agar meningkatkan motivasi mereka dalam budidaya ayam joper. Potensi dan prospek maggot sebagai pengganti bahan pakan sumber protein yang murah dapat menurunkan biaya pakan, sehingga diharapkan dapat meningkatkan motivasi santri tani dalam usaha peternakan. Motivasi adalah sebuah situasi yang mendorong seseorang agar mau melaksanakan sesuatu. Sobur (2016) 
menyatakan bahwa motif merupakan dorongan, hasrat, keinginan, dan tenaga penggerak lainnya, yang berasal dari dalam dirinya untuk melakukan sesuatu. Selanjutnya, Kurnia (2000) berpendapat bahwa rataan pekerja yang termotivasi menggunakan 80 90\% kemampuan dalam bekerja dan mereka yang tidak termotivasi hanya memakai 20$30 \%$ kemampuannya dalam bekerja. Oleh karena itu, motivasi yang tinggi diperlukan bagi keberhasilan suatu program.

Bidang ilmu motivasi erat kaitannya dengan suatu pembelajaran formal maupun non formal. Pondok pesantren merupakan lingkup pendidikan formal dan non formal dengan budaya yang agamis, kekeluargaan dan tingkat kepatuhan sangat tinggi. Adanya program peternakan yang masuk di lingkup ponpes menambah keterampilan dari santri-santrinya. Guna memajukan sektor peternakan yang berorientasi pada keuntungan usaha, maka perlu upanya meningkatkan keterampilan santri. Sebelum beranjak kepada keterampilan santri, perlu diketahui terlebih dahulu mengenai motivasi yang mandasari santri mau melakukan kegiatan peternakan itu sendiri. Hal ini bertujuan untuk mengetahui strategi pembelajaran seperti apa yang tepat untuk meningkatkan keterampilan santri.

Berdasarkan kondisi tersebut maka perlu dilakukan penelitian tentang Motivasi Santri Tani dalam Budidaya Black Soldier Fly (BSF) di Kelompok Santri Tani Milenial Kecamatan Kedungkandang Kota Malang. Tujuan dari penelitian ini adalah mengetahui tingkat motivasi dan faktor-faktor yang mempengaruhi motivasi santri tani dalam budidaya BSF sebagai pakan alternatif ayam joper. Parameter yang diukur untuk faktor-faktor yang mempengaruhi motivasi santri tani dalam budidaya BSF adalah umur, pendidikan, sifat kosmopolitan dan kepemimpinan partisipatif.

\section{METODE}

\section{Waktu dan Tempat Penelitian}

Penelitian dilakukan pada bulan Maret sampai dengan Juni 2020 bertempat di Kelompok Santri Tani Milenial (KSTM) Kecamatan Kedungkandang Kota Malang Jawa Timur.

\section{Metode Penelitian}

Metode yang digunakan dalam penelitian ini adalah pendekatan kuantitatif dengan metode survey. Populasi pada penelitian ini adalah anggota KSTM di Kecamatan Kedungkandang Kota Malang sebanyak 180 orang. Sampel penelitian ini sebanyak 66 orang ditentukan melalui teknik cluster random sampling atau area sampling yang dihitung berdasarkan rumus slovin.

Pengumpulan data primer yang digunakan adalah melalui pengisian kuesioner tertutup dengan alat pengukuran menggunakan metode skala Likert. Validitas dan reliabilitas kuesioner pada penelitian ini menggunakan kesepakatan ahli (expert judgement). Expert atau ahli adalah orang yang memiliki kepakaran pada bidang yang sesuai dengan instrumen penelitian (Retnawati, 2016). 3 orang ahli yang turut berpartisipasi dalam penilaian validitas dan reliabilitas kuesioner.

\section{Analisis Data}

Analisis data menggunakan analisis deskriptif dan regresi linier berganda. Tingkat motivasi santri tani diketahui dengan melakukan analisis deskriptif kuantitatif. Data yang diperoleh dihitung sesuai bobot soal yaitu $20 \%$ setiap soal, selanjudnya dihitung nilai rata-rata. Skor total bergerak dari skor terendah $20(1 \times 20)$ sampai degan skor tertinggi $100(5 \times 20)$. Skor yang diperoleh dihitung dalam bentuk persentase, sebagai berikut:

$$
x=\frac{a}{b} X 100 \%
$$

Keterangan:

$\mathrm{x}=$ Skor per individu

$\mathrm{a}=$ Skor yang diperoleh

$\mathrm{b}=$ Skor maksimal 
Setelah dihitung skor perindividu responden lalu ditentukan rata-rata motivasi semua responden untuk mengetahui tingkat motivasi secara keseluruhan satu kelompok, sebagai berikut:

$$
\bar{X}=\frac{\sum n}{m} x 100 \%
$$

Keterangan:

$(\bar{X})=$ Rata-rata motivasi santri tani dalam 1 kelompok

$\sum \mathrm{n}=$ Jumlah persentase skor individu

$\mathrm{m}$ = persentase skor maksimal

Tabel 1. Kategori Tingkat Motivasi

\begin{tabular}{lc}
\hline Kelas Interval & Predikat \\
\hline $84 \% \leq \leq 100 \%$ & Sangat tinggi \\
$68 \% \leq<84 \%$ & Tinggi \\
$52 \% \leq<68 \%$ & Sedang \\
$36 \% \leq<52 \%$ & Rendah \\
$20 \% \leq<36 \%$ & Sangat rendah \\
\hline
\end{tabular}

Sumber: Data Terolah, 2020.

Data faktor-faktor yang berpengaruh pada motivasi santri tani dalam budidaya BSF di analisis menggunakan uji regresi linier berganda (Silalahi, 2017). Model rumus matematis dalam regresi linier berganda yaitu sebagai berikut:

$$
\mathbf{Y}=\mathbf{a}+\mathbf{b}_{1} \mathbf{X}_{1}+\mathbf{b}_{2} \mathbf{X}_{2}+\mathbf{b}_{3} \mathbf{X}_{3}+\mathbf{b}_{4} \mathbf{X}_{4}+\mathbf{e}
$$

Keterangan:

$\mathrm{Y}=$ Motivasi santri tani dalam budidaya BSF

a $=$ Nilai Konstanta

bn $=$ Nilai Koefisien regresi

$\mathrm{e}=$ Kesalahan penganggu

$\mathrm{X} 1=$ Umur

$\mathrm{X} 2$ = Tingkat pendidikan formal

X3 = Sifat kosmopolitan

$\mathrm{X} 4=$ Kepemimpinan partisipatif

Variabel independen muncul berdasarkan pengamatan secara langsung terhadap sampel penelitian selama 3 bulan. Selain itu, juga memperhatikan penelitian terdahulu mengenai faktor-faktor yang mempengaruhi motivasi.

\section{HASIL DAN PEMBAHASAN}

\section{Karakteristik Responden}

Kelompok Santri Tani Milenial (KSTM) Kecamatan Kedungkandang Kota Malang tersebar di enam ponpes diantaranya Darussalam Agung, Al-Hayatul Islamiyah, Darussalam, Nurul Muttaqin Al Barokah, Baitul Makmur, dan Miftahul Ulum. Anggota dari setiap KSTM terdiri dari 30 orang yang merupakan pengurus pondok, santri dan santriwati, sehingga total dari seluruh anggota KSTM Kota Malang sebanyak 180 orang. Peternak milenial memiliki karakteristik yang beragam di berbagai daerah, maka dari itu cara penyampaian saat berkomunikasi harus disesuai dengan kondisi sasaran. Perlu strategi yang tepat untuk menyampaikan informasi dalam penyuluhan pertanian, agar sasaran tertarik dan mampu menyerap informasinya. Dalam penelitian ini karakteristik yang dilihat diantaranya umur, pendidikan formal, sifat kosmopolitan dan kepemimpinan partisipatif.

Umur peternak dalam penelitian ini adalah waktu keberadaan peternak yang diukur sejak lahir hingga penelitian dilakukan, diukur dalam satuan tahun. Menurut undangundang tenaga kerja no. 13 tahun 2003 bahwa orang yang memiliki usia produktif adalah $>15$ sampai dengan $<64$ tahun. Dengan usia berikut bisa bekerja secara maksimal dan memberikan hasil yang lebih banyak di bandingkan dengan usia yang kurang produktif. Berdasarkan pengamatan yang dilakukan di KSTM Kota Malang, kebanyakan remaja-remaja belum bekerja dan belum memiliki pengalaman dibidang peternakan. Sedangkan $12,1 \%$ yaitu pada rentang usia 26 - 35 tahun dan $6,1 \%$ pada rentang usia 36 - 45 tahun tergolong pada taraf orang dewasa yang bekerja untuk menghidupi keluarganya dan dirinya sendiri (Tabel 1).

Tingkat pendidikan formal dalam penelitian ini adalah tingkat pendidikan formal yang telah dilalui peternak hingga penelitian ini dilakukan. Anggota KSTM menurut tingkat pendidikannya $48,5 \%$ telah tamat SMA atau sederajat (Tabel 2). Hal ini 
Tabel 1. Karakteristik Berdasarkan Umur

\begin{tabular}{cccc}
\hline No. & Umur (tahun) & Responden $(\mathrm{N})$ & Persentase $(\%)$ \\
\hline 1. & $15-25$ & 54 & 81,8 \\
2. & $26-35$ & 8 & 12,1 \\
3. & $36-45$ & 4 & 6,1 \\
\hline Jumlah & & 66 & 100 \\
\hline
\end{tabular}

Sumber: Data terolah, 2020.

Tabel 2. Karakteristik Berdasarkan Pendidikan

\begin{tabular}{cccc}
\hline No. & Tingkat Pendidikan & Responden $(\mathrm{N})$ & Persentase $(\%)$ \\
\hline 1. & SD & 1 & 1,5 \\
2. & SMP & 21 & 31,8 \\
3. & SMA & 32 & 48,5 \\
4. & S1 & 11 & 16,7 \\
5. & S2 & 1 & 1,5 \\
\hline Jumlah & & 66 & 100 \\
\hline
\end{tabular}

Sumber: Data terolah, 2020.

menandakan kualitas SDM yang dimiliki termasuk baik.

Dengan adanya SDM yang berkualitas baik semakin lama KSTM Kota Malang menjadi semakin maju dibidang pemanfaatan sumber daya alam yang tersedia, karena mereka lebih mudah untuk menyerap inovasi yang diberikan. Menurut Soekarwati (tahun) dalam Farida dan Wardiny (2013), mereka yang berpendidikan tinggi adalah relatif lebih cepat dalam melaksanakan adopsi teknologi, begitu pula sebaliknya mereka yang berpendidikan rendah agak sulit untuk melaksanakan adopsi inovasi dengan cepat.

Kosmopolit dalam penelitian ini adalah keterbukaan individu terhadap dunia luar, mau untuk mengakses informasi dibidang peternakan dan kemauan untuk belajar pada orang yang lebih ahli disuatu bidang.

Tingkat kosmopolitan santri tani sangatlah beragam, hal ini disebabkan karena latarbelakang responden adalah santri yang masih bersekolah dan terbatasi dalam penggunaan gadget. Golongan yang memiliki tingkat kosmopolitan rendah sebanyak $19,7 \%$ dan sangat rendah $15,2 \%$ dicirikan dengan jarang menggunakan gadget dan jarang keluar dari lingkungan pondok dengan tujuan penggalian informasi budidaya maggot BSF (Tabel 3). Menurut Mardikanto dan Sri Sutarni dalam Khasanah (2008) Tingkat kekosmopolitan manusia merupakan karakteristik yang mempunyai hubungan dan pandangan yang luas dengan dunia luar (keluar dari linkungannya untuk menambah wawasan), dengan kelompok sosial lain juga mobilitas yang tinggi.

Sedangkan anggota KSTM yang memiliki partisipasi sosial yang lebih tinggi dan mampu mengakses media massa cenderung memiliki tingkat kosmopolitan sangat tinggi, tinggi dan sedang. Anggota yang tergabung dalam golongan ke dua ini rata-rata sudah alumni pondok yang masih mengabdi dan pengurus KSTM. Mereka pada golongan ke dua memiliki kesempatan lebih banyak untuk keluar pondok dan juga mengakses informasi melalui media. Keluar pondok yang dimaksut adalah berjelajah di dunia luar untuk belajar pada orang yang lebih ahli mengenai budidaya maggot BSF.

Kepemimpinan partisipatif dalam penelitian ini adalah gaya kepemimpinan 
Tabel 3. Karakteristik Berdasarkan Sifat Kosmopolitan

\begin{tabular}{lccc}
\hline Tingkat Kosmopolitan & Nilai & Responden $(\mathrm{N})$ & Persentase (\%) \\
\hline Sangat Tinggi & $84-100$ & 9 & 13,6 \\
Tinggi & $68-83$ & 18 & 27,3 \\
Sedang & $52-67$ & 16 & 24,2 \\
Rendah & $36-51$ & 13 & 19,7 \\
Sangat Rendah & $20-35$ & 10 & 15,2 \\
\hline Jumlah & & 66 & 100 \\
\hline
\end{tabular}

Sumber: Data terolah, 2020.

Tabel 4. Karakteristik Berdasarkan Sifat Kepemimpinan Partisipatif

\begin{tabular}{lccc}
\hline Tingkat Kepemimpinan Partisipatif & Nilai & Responden $(\mathrm{N})$ & Persentase (\%) \\
\hline Sangat Tinggi & $84-100$ & 16 & 24,2 \\
Tinggi & $68-83$ & 16 & 24,2 \\
Sedang & $52-67$ & 12 & 18,2 \\
Rendah & $36-51$ & 15 & 22,7 \\
Sangat Rendah & $20-35$ & 7 & 10,6 \\
\hline Jumlah & & 66 & 100 \\
\hline
\end{tabular}

Sumber: Data terolah, 2020.

yang menunjukkan suatu dorongan dari pimpinan terhadap kemampuan bawahan dalam mengambil keputusan. Mayoritas tingkat kepemimpinan partisipatif di KSTM Kota Malang yaitu tinggi dan sangat tinggi yang masing-masing mencapai $24,2 \%$. Sesuai dengan pengamatan di lokasi bahwa pengurus dan anggota bersama-sama terlibat dalam pemecahan masalah dan pengambilan keputusan dengan musyawarah, serta komunikasi dua arah semakin meningkat untuk mencapai mufakat. Namun disisi lain, masih terdapat cukup banyak kondisi ditingkat kepemimpinan partisipatif rendah hingga sangat rendah berturut-turut $22,7 \%$ dan $10,6 \%$, serta pada tingkat sedang 18,2\% (Tabel 4). Kondisi ini dapat terjadi dikarenakan banyak faktor diantaranya anggota belum cukup dewasa untuk menghadapi permasalahan, tidak terjadi komunikasi dengan baik, keputusan yang dibuat memberatkan sebelah pihak dan bisa juga pemimpin yang kurang menerima masukan dari anggotanya.

\section{Tingkat Motivasi}

Motivasi adalah dorongan atau motif yang menggerakan seseorang untuk melakukan suatu tindakan untuk mencapai tujuan. Besarnya dorongan tergantung pada tujuan yang ingin dicapai. Tingkat motivasi anggota KSTM dalam budidaya BSF sangat beragam, sehingga diperoleh rerata tingkat motivasi sebesar $56,5 \%$ yang termasuk pada tingkatan sedang (Tabel 5). Keberagaman tingkat motivasi anggota KSTM dalam budidaya maggot BSF disebabkan oleh banyak faktor diantaranya umur, pendidikan, kosmopolitan dan kepemimpinan partisipatif serta faktor lain yang tidak diteliti. Menurut teori Maslow, motivasi digolongkan pada lima tingkat kebutuhan (five hierarchy of needs) yaitu kebutuhan aktualisasi diri, kebutuhan penghargaan, kebutuhan sosial, kebutuhan rasa aman dan kebutuhan fisiologis.

Keberagaman tingkat motivasi anggota KSTM dalam budidaya maggot BSF juga dipengaruhi oleh tingkat kebutuhan masingmasing individu. Tingginya tingkat kebutuhan membuat semakin tinggi pula dorongan pada diri anggota KSTM untuk melakukan kegiatan budidaya maggot BSF. Bentuk dorongan 
Tabel 5. Tingkat Motivasi Santri Tani

\begin{tabular}{llcccc}
\hline No & Tingkat Motivasi & Nilai & $\begin{array}{c}\text { Responden } \\
(\mathrm{N})\end{array}$ & $\begin{array}{c}\text { Persentase } \\
(\%)\end{array}$ & Rata-rata \\
\hline 1. & Sangat Tinggi & $84 \% \leq \leq 100 \%$ & 16 & 24,2 & \\
2. & Tinggi & $68 \% \leq<84 \%$ & 9 & 13,6 & \\
3. & Sedang & $52 \% \leq<68 \%$ & 12 & 18,2 & $56,5 \%$ \\
4. & Rendah & $36 \% \leq<52 \%$ & 21 & 31,8 & Tingkat sedang \\
5. & Sangat Rendah & $20 \% \leq<36 \%$ & 8 & 12,1 & \\
\hline & Jumlah & & 66 & 100 & \\
\hline
\end{tabular}

Sumber: Data terolah, 2020.

untuk mencapai tujuan tersebut memotivasi seseorang dalam melakukan sesuatu, sehingga hasil yang diperoleh lebih baik dari pada tidak termotivasi. Sejalan dengan Kurnia (2000) bahwa rataan pekerja yang termotivasi menggunakan $80 \%$ - 90\% kemampuan dalam bekerja dan mereka yang tidak termotivasi hanya memakai $20 \%$ - 30\% kemampuannya dalam bekerja. Tingkat kebutuhan anggota KSTM tidak sama antara individu satu dengan yang lainnya. Kondisi tingkat motivasi dalam budidaya maggot BSF ini belum mencapai optimal, karena masih terdapat anggota yang berada pada tingkat motivasi rendah $(31,8 \%)$, dan bahkan tingkat motivasi sangat rendah $(12,1 \%)$ (Gambar 1).

Tingkat motivasi berdasarkan kebutuhan fisiologis lebih dominan yaitu sebesar 24,5\% (Gambar 1). Artinya dalam budidaya maggot BSF anggota KSTM memiliki motivasi utama $24,5 \%$ yaitu untuk memenuhi kebutuhan hidupnya (primer). Hal tersebut sesuai dengan hasil penelitian Ginting (2018) yang menyatakan bahwa pemenuhan kebutuhan dasar (fisiologis) selalu menjadi pemenuhan yang bersifat mendesak karena merupakan pemenuhan dalam jangka waktu pendek. Menurut pendapat Sobur (2016) fisiologis sendiri adalah kebutuhan yang paling dasar, paling kuat, dan paling jelas di antara segala kebutuhan manusia. Anggota KSTM merasakan dalam budidaya maggot BSF jika dikelola dengan baik dapat meningkatkan penghasilan pondok dengan menekan biaya oprasional pakan ternak.
Selain itu, mereka merasa budidaya maggot BSF dapat menjadi salah satu alternative usaha yang berkelanjutan setelah keluar dari pondok.

Tingkat motivasi anggota KSTM berdasarkan kebutuhan rasa aman mencapai $21,5 \%$ dapat dilihat pada Gambar 1. Artinya dalam budidaya maggot BSF anggota KSTM memiliki motivasi sebesar $21,5 \%$ yaitu untuk memenuhi kebutuhan rasa aman. Hal tersebut menggambarkan kondisi di lapangan bahwa anggota KSTM mendapatkan dukungan sepenuhnya oleh pihak pondok dan tidak ada tekanan/paksaan dari pihak manapun. Mereka merasakan suasana nyaman pada saat berkelompok dengan saling mempercayai satu dengan yang lainnya, dan saling melindungi kepentingan masing-masing. Sejalan dengan penelitian yang dilakukan Sari (2018) menyatakan bahwa suasana kerja yang nyaman merupakan faktor motivasi tertinggi berdasarkan kebutuhan rasa aman. Kebutuhan rasa aman muncul sebagai kebutuhan yang paling penting jika kebutuhan psikologis telah terpenuhi (Sobur, 2016).

Tingkat motivasi anggota KSTM berdasarkan kebutuhan sosial, dimana tidak terlalu berbeda jauh dengan kebutuhan rasa aman yaitu sebesar $21,1 \%$ (Gambar 1$)$. Artinya dalam budidaya maggot BSF anggota KSTM memiliki motivasi sebesar $21,1 \%$ yaitu untuk memenuhi kebutuhan sosial. Kondisi tersebut dikarenakan anggota KSTM merasakan dengan ikut berperan dalam budidaya maggot BSF dapat lebih dipercaya oleh pondok. 


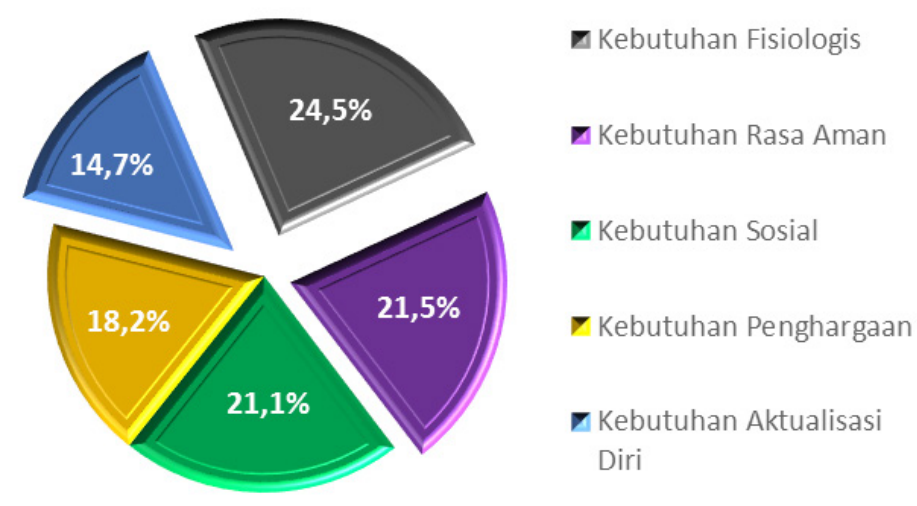

Gambar 1. Presentase Tingkat Motivasi Anggota KSTM Bedasarkan Kebutuhan Maslow (Data Terolah, 2020)

Selain itu interaksi antara anggota KSTM dan pihak pondok menjadi lebih sering, serta lebih akrab antar personal kelompok, saling tolong menolong dan saling menghormati. Kondisi tersebut sesuai dengan penelitian Sari (2018) menyatakan bahwa faktor motivasi tertinggi berdasarkan kebutuhan sosial ialah rasa solidaritas antar sesama dengan saling tolong menolong jika mengalami kesulitan dalam menyelesaikan pekerjaan. Kebutuhan sosial muncul ketika kebutuhan sebelumnya telah dipenuhi secara rutin (Sobur, 2016). Sehingga anggota KSTM yang sudah merasakan kebutuhan sosial berarti telah terpenuhi dua kebutuhan sebelumnya.

Tingkat motivasi anggota KSTM berdasarkan kebutuhan penghargaan mencapai 18,2\% (Gambar 1). Artinya dalam budidaya maggot BSF anggota KSTM memiliki motivasi sebesar 18,2\% yaitu untuk memenuhi kebutuhan penghargaan. Kondisi tersebut dikarenakan anggota KSTM merasa jika pesantren memiliki usaha budidaya maggot BSF untuk pakan alternatif, maka pesantren lebih bermatabat/terhormat, serta orang tua/wali santri merasa bangga terhadap kopetensi yang dimiliki anaknya. Selain itu, santri lainnya akan lebih sungkan dan santri yang ditugasi mengelola usaha peternakan ini merupakan santri terpilih serta diberi kepercayaan oleh ketua KSTM. Sesuai dengan penelitian yang dilakukan oleh Sari (2018) bahwa faktor motivasi tertinggi berdasarkan kebutuhan penghargaan adalah kebijakasanan pimpinan dalam memberikan kepercayaan lebih untuk naik jabatan bagi pegawai dengan kinerja memuaskan.

Tingkat motivasi anggota KSTM berdasarkan kebutuhan aktualisasi diri yaitu sebesar 14,7\% (Gambar 1). Artinya dalam budidaya maggot BSF anggota KSTM memiliki motivasi sebesar $14,7 \%$ yaitu untuk memenuhi kebutuhan aktualisasi diri. Menurut Sobur (2016) aktualisasi diri merupakan suatu tujuan yang tidak pernah dapat dicapai sepenuhnya. Anggota KSTM tidak secara keseluruhan merasakan kebutuhan aktualisasi diri dikarenakan sulit untuk mencapainya. Namun terdapat anggota yang merasakannya, kondisi tersebut dikarenakan sebagian anggota KSTM merasa mempunyai harga diri lebih baik jika mampu menyediakan pakan ternak yang lebih ekonomis dengan memanfaatkan maggot BSF. Selain itu dengan budidaya maggot BSF mampu menggambarkan martabat dan harga diri anggota KSTM dengan memperlihatkan kemampuan atau kompetensi yang tidak dimiliki oleh orang lain. Sesuai dengan penelitian yang dilakukan oleh Sari (2018) 
Tabel 6. Hasil Uji Asumsi Klasik

\begin{tabular}{|c|c|c|c|}
\hline No. & Uji & Hasil & Keputusan \\
\hline 1. & Normalitas Data & $\begin{array}{l}\text { Titik-titik menyebar mengikuti } \\
\text { garis diagonalnya }\end{array}$ & $\begin{array}{c}\text { Data Berdistribusi } \\
\text { Normal }\end{array}$ \\
\hline 2. & Multikolinearitas & $\begin{array}{l}\text { Nilai tolerance }>0,1 \text { dan nilai } \\
\text { VIF }<10 \text { pada seluruh variabel } \\
\text { independen }\end{array}$ & $\begin{array}{c}\text { Tidak terjadi } \\
\text { multikolinearitas }\end{array}$ \\
\hline 3. & Heteroskedastisitas & $\begin{array}{c}\text { Titik-titik menyebar diatas dan } \\
\text { dibawah angka } 0 \text { pada sumbu Y } \\
\text { secara tidak beraturan dan tidak } \\
\text { membentuk suatu pola }\end{array}$ & $\begin{array}{c}\text { Tidak terjadi } \\
\text { Heteroskedastisitas }\end{array}$ \\
\hline
\end{tabular}

Sumber: Data terolah, 2020.

bahwa faktor motivasi tertinggi berdasarkan kebutuhan aktualisasi diri adalah pekerjaan yang dikerjakan sesuai dengan kompetensi/ kemampuan yang dimiliki karyawan.

\section{Faktor-faktor yang Mempengaruhi Motivasi Santri Tani dalam Budidaya Maggot BSF}

Faktor-faktor yang berpengaruh pada motivasi santri tani dalam budidaya maggot BSF di analisis menggunakan uji regresi linear berganda. Variabel independen yang diujikan terhadap variabel dependen yaitu (X1) umur, (X2) tingkat pendidikan, (X3) kosmopolit, dan (X4) kepemimpinan partisipatif dan variabel dependen adalah motivasi.

Berdasarkan hasil uji asumsi klasik, kondisi data telah berdistribusi normal, tidak terjadi multikolinearitas dan tidak terjadi heteroskedastisitas (Tabel 6). Sehingga data dapat dianalisis menggunakan regresi linear berganda untuk mengetahui faktor-faktor yang mempengaruhi motivasi.

\section{Pengaruh Secara Simultan}

Pengaruh faktor-faktor secara simultan atau bersamaan dapat disimpulkan berdasarkan hasil uji $\mathrm{F}$ simultan dengan melihat nilai signifikasi dan atau nilai Fhitung yang diperoleh. Diketahui bahwa variabel independen umur, pendidikan, kosmopolitan, dan kepemimpinan partisipatif secara simultan berpengaruh terhadap variabel dependen motivasi anggota KSTM dalam budidaya maggot BSF. Sesuai dengan penelitian yang dilakukan (Sudarko dan Ridjal, 2017) bahwa umur petani kopi, pendidikan formal petani kopi, pendidikan nonformal petani, pengalaman berusahatani kopi, jumlah tanggungan keluarga, luas lahan garapan, dan akses informasi merupakan faktor-faktor yang berpengaruh signifikan terhadap motivasi petani kopi rakyat dalam diversifikasi pengolahan primer dan sekunder kopi di Kabupaten Jember. Dilengkapi oleh penelitian yang dilakukan (Sumiati, 2011) bahwa faktor karakteristik petani yang berhubungan dengan motivasi petani melakukan kegiatan agroforestri yaitu umur, tingkat pendidikan, kepemilikan lahan, pengalaman berusahatani, persepsi, status sosial, dan sifat kosmopolitan. Sedikit terdapat perbedaan dikarekan belum ada penelitian yang menggunakan variabel independent seperti pada penelitian ini secara bersamaan. Pengaruh faktor secara simultan belum tentu sama ketika dilihat pengaruhnya secara parsial.

Hasil analisis model summary menunjukkan nilai $\mathrm{R}$ square sebesar 0,730 . Nilai tersebut artinya pengaruh faktor umur, pendidikan, kosmopolitan, dan kepemimpinan partisipatif secara bersamaan terhadap motivasi sebesar $73 \%$ sedangkan sisanya $27 \%$ dipengaruhi oleh faktor lain yang tidak diteliti. Persentase pengaruh lebih kecil dari pada penelitian yang dilakukan (Ardi dan Effendi, 2018) menyatakan bahwa pengaruh umur, pendidikan, luas lahan, dan 
jumlah tanggungan terhadap motivasi petani dalam melakukan usahatani semangka di Desa Sumber Sari sebesar 80,20\% sedangkan sisanya $19,80 \%$ dipengaruhi oleh variabel lain. Hal ini bisa terjadi dikarenakan variabel yang digunakan dan jenis usaha tani yang dilaksanakan berbeda.

\section{Pengaruh Secara Parsial}

Pengaruh variabel independen umur, pendidikan formal, sifat kosmopolitan, dan kepemimpinan partisipatif terhadap variabel dependen motivasi santri tani dalam budidaya BSF secara parsial atau masing-masing berdasarkan hasil uji $\mathrm{T}$ dapat disimpulkan sebagai berikut:

\section{Umur}

Faktor umur pada penelitian ini tidak berpengaruh signifikan terhadap motivasi anggota KSTM dalam budidaya maggot BSF, dilihat berdasarkan hasil uji $\mathrm{T}$ parsial. Sesuai dengan penelitian yang dilakukan oleh (Ardi dan Effendi, 2018) bahwa umur secara parsial tidak mempengaruhi motivasi petani dalam melakukan usahatani semangka di Desa Sumber Sari. Hal ini disebabkan oleh responden penelitian dengan tingkat motivasi tinggi tidak hanya berasal dari satu golongan umur, melainkan pada sebagian responden dari usia muda, dewasa hingga lansia bermotivasi tinggi dalam budidaya baggot BSF. Jika dilihat berdasarkan analisis sumbangan efektif dan sumbangan relatif umur berpengaruh hanya sebesar $1 \%$ terhadap motivasi anggota KSTM. Serta berdasarkan persamaan regresi linear berganda setiap peningkatan umur sebesar 1 , maka motivasi akan meningkat 0,027 dengan asumsi variabel independen lain nilainya tetap.

\section{Pendidikan Formal}

Faktor pendidikan formal pada penelitian ini berpengaruh signifikan terhadap motivasi anggota KSTM dalam budidaya maggot BSF, dilihat berdasarkan hasil uji $\mathrm{T}$ parsial. Berbeda dengan hasil penelitian yang dilakukan oleh Hendarto et al. (2012) menyatakan bahwa variabel pendidikan tidak berhubungan nyata dengan tingkat motivasi anggota koperasi BMT. Sama halnya dengan penelitian yang dilakukan olehArdi dan Effendi (2018) yang menyatakan bahwa pendidikan secara parsial tidak mempengaruhi motivasi petani melakukan usahatani semangka di Desa Sumber Sari. Hal ini disebabkan oleh responden penelitian dengan tingkat motivasi tinggi berasal dari golongan SMA keatas, selain itu responden dengan pendidikan di bawah SMA bermotivasi sangat rendah dalam budidaya baggot BSF. Jika dilihat berdasarkan analisis sumbangan efektif dan sumbangan relatif pendidikan formal berpengaruh hanya sebesar $13 \%$ terhadap motivasi anggota KSTM. Serta berdasarkan persamaan regresi linear berganda setiap peningkatan pendidikan sebesar 1, maka motivasi akan meningkat 0,219 dengan asumsi variabel independen lain nilainya tetap.

\section{Sifat Kosmopolitan}

Faktor sifat kosmopolitan pada penelitian ini berpengaruh signifikan terhadap motivasi anggota KSTM dalam budidaya maggot BSF, dilihat berdasarkan hasil uji $\mathrm{T}$ parsial. Artinya sifat kosmopolitan anggota KSTM dapat meningkatkan motivasi dalam budidaya maggot BSF. Sesuai dengan hasil penelitian yang dilakukan oleh (Zainuddin et al., 2016) yang menyatakan bahwa semakin kuat sifat kosmopolit petani dapat meningkatkan motivasi petani tersebut dalam berusahatani lada, begitu pula sebaliknya. Hal ini disebabkan responden penelitian adalah santri yang masih bersekolah dan terbatasi dalam penggunaan gadget dengan tujuan penggalian informasi mengenai budidaya maggot BSF. Sehingga mereka merasa membutuhkan pembaruan informasiinformasi didunia peternak terutama budidaya maggot BSF. Selain pembaharuan informasi melalui gadget mereka juga merasa membutuhkan kesempatan untuk keluar pondok dengan tujuan berjelajah di dunia luar untuk belajar pada orang yang lebih ahli mengenai budidaya maggot BSF. Jika dilihat berdasarkan analisis sumbangan efektif dan sumbangan relatif sifat kosmopolitan berpengaruh sebesar 53\% terhadap motivasi 
anggota KSTM. Serta berdasarkan persamaan regresi linear berganda setiap peningkatan sifat kosmopolitan sebesar 1, maka motivasi akan meningkat 0,514 dengan asumsi variabel independen lain nilainya tetap.

\section{Kepemimpinan Partisipatif}

Faktor kepemimpinan partisipatif pada penelitian ini berpengaruh signifikan terhadap motivasi anggota KSTM dalam budidaya maggot BSF, dilihat berdasarkan hasil uji $\mathrm{T}$ parsial. Artinya kepemimpinan partisipatif pimpinan KSTM dapat meningkatkan motivasi dalam budidaya maggot BSF. Sesuai dengan hasil penelitian yang dilakukan oleh Rizqiyah et al. (2017) menyatakan bahwa gaya kepemimpinan partisipatif secara parsial berpengaruh signifikan terhadap motivasi kerja karyawan. Dilengkapi juga dengan hasil penelitian Soelistya (2014) yang menyatakan bahwa kepemimpinan partisipatif signifikan mempengaruhi motivasi kerja pegawai Maspion Group Surabaya Jawa Timur. Hal ini dikarenakan pengurus dan anggota KSTM bersama-sama terlibat dalam pemecahan masalah dan pengambilan keputusan dengan musyawarah, serta komunikasi dua arah semakin meningkat untuk mencapai mufakat. Selain Itu ketua KSTM juga memberikan kesempatan bagi anggota untuk mengembangkan ilmu dalam budidaya maggot BSF serta ikut andil dalam merumuskan keberlanjutan usaha peternakan di pondok. Berbeda dengan penelitian yang dilakukan oleh Setiawan (2017) yang menyatakan bahwa gaya kepemimpinan partisipatif tidak berpengaruh signifikan terhadap motivasi kerja karyawan PT. Asri Motor. Jika dilihat berdasarkan analisis sumbangan efektif dan sumbangan relatif kepemimpinan partisipatif berpengaruh sebesar 33\% terhadap motivasi anggota KSTM. Serta berdasarkan persamaan regresi linear berganda setiap peningkatan kepemimpinan partisipatif sebesar 1, maka motivasi akan meningkat 0,351 dengan asumsi variabel independen lain nilainya tetap.

\section{KESIMPULAN}

Tingkat motivasi anggota KSTM dalam budidaya BSF rata-rata pada tingkat sedang. Sehingga perlu adanya penyuluhan dan pelatihan secara berkesinambungan kepada anggota KSTM agar dapat meningkatkan motivasi dalam budidaya maggot BSF guna mengurangi biaya pakan.

Selain itu Faktor pendidikan, sifat kosmopolitan dan kepemimpinan partisipatif berpengaruh signifikan terhadap motivasi santri tani dalam budidaya BSF sebagai pakan alternatif. Sehingga guna meningkatkan motivasi anggota KSTM harus lebih membuka diri dengan dunia luar bisa melalui media sosial (android, TV, radio, surat kabar) maupun belajar secara langsung kepada orang yang lebih ahli dalam budidaya maggot BSF.

\section{DAFTAR PUSTAKA}

Ardi, M. R. dan Effendi, M. 2018. FaktorFaktor Yang Memotivasi Petani Dalam Melakukan Usahatani Semangka (Citrullus vulgaris S.) di Desa Sumber Sari Kecamatan Kota Bangun Kabupaten Kutai Kartanegara. Jurnal Agribisnis dan Komunikasi Pertanian, 1(2): 98-103.

Azir, A., Harris, H., dan Haris, R. B. K. 2017. Produksi dan Kandungan Nutrisi Maggot (Chrysomya megacephala) Menggunakan Komposisi Media Kultur Berbeda. 12: 34-40.

Farida, I. dan Wardiny, I. T. M. 2013. Tingkat Keberdayaan Petani Melalui Gabungan Kelompok Tani Di Kecamatan Ciruas, Kabupaten Serang, Provinsi Banten. Banten: Universitas Terbuka.

Ginting, P. A. 2018. Implementasi Teori Maslow dan Peran Ganda Pekerja Wanita K3L Universitas Padajajaran. Jurnal Pekerjaan Sosial. 1: 220-233.

Hendarto, Badrudin, R., dan Yuliarso, M. Z. 2012. Faktor-Faktor Yang Berhubungan dengan Tingkat Motivasi Petani Sawit 
dalam Pengembalian Kredit di Koperasi Baitul Maal Watamwil Desa Srikaton Kecamatan Pondok Kelapa Kabupaten Bengkulu Tengah. Jurnal Agrisep. 11: 22-34.

Katayane, F. A., Bagau, B., F.R.Wolayan, dan M. R.Imbar. 2014. Produksi Dan Kandungan Protein Maggot (Hermetia illucens) Dengan Menggunakan Media Tumbuh Berbeda. Jurnal Zootek, 34, 27-36.

Kemenag. 2019. Statistik Pesantren. Retrieved From Pangkalan Data Pondok Pesantren Kementerian Agama Website: Https:// Ditpdpontren.Kemenag.Go. Id/Pdpp.

Khasanah, W. 2008. Hubungan Faktor-Faktor Sosial Ekonomi Petani Dengan Tingkat Adopsi Inovasi Teknologi Budidaya Tanaman Jarak Pagar (Jatropha curcas L.) di Kecamatan Lendah Kabupaten Kulon Progo. Universitas Sebelas Maret.

Kurnia, W. 2000. Analisis Produktivitas Tenaga Kerja Dan Faktor Yang Mempengaruhinya Di PT. Saung Mirwan, Cisarua, Bogor.

Retnawati, H. 2016. Analisi Kuantitatif Instrumen Penelitian (Panduan Peneliti, Mahasiswa, dan Psikometrian). Yogyakarta: Parama Publishing.

Sari, E. 2018. Pendekatan Hierarki Abraham Maslow Pada Prestasi Kerja Karyawan Pt. Madubaru (Pg Madukismo) Yogyakarta Abraham. 6(1): 58-77.

Setiawan, A. 2017. Pengaruh Gaya Kepemimpinan Partisipatif Terhadap Kinerja Karyawan Melalui Motivasi Kerja Dan Kepuasan Kerja. Jurnal Agora. 3:1-7.

Silalahi, U. 2017. Metode Penelitian Sosial
Kuantitatif. Bandung: Refika Aditama.

Sobur, A. 2016. Psikologi Umum Edisi Revisi. Bandung: CV Pustaka Setia.

Soelistya, D. 2014. Pengaruh Gaya Kepemimpinan Partisipatif Dan Komunikasi Terhadap Motivasi Kerja Serta Dampaknya Pada Prestasi Kerja Pegawai di Maspion Group Surabaya Jawa Timur. Jurnal Ilmu Ekonomi \& Manajemen. 1(1): 1-10.

Sudarko dan Ridjal, J. A. 2017. Peningkatan Motivasi Petani Kopi Rakyat Dalam Diversifikasi Pengolahan Produk Primer Dan Sekunder Kopi Dengan Pendekatan Agribisnis Di Kabupaten Jember [Improving]. Jurnal Ilmu-Ilmu Pertanian, 192-198.

Sumiati. 2011. Analisis Kelayakan Finansial Dan Faktor-Faktor Yang Memotivasi Petani Dalam Kegiatan Agroforestri. Bogor: Institut Pertanian Bogor.

Veldkamp, T., Duinkerken, G. Van, Huis, A. Van, Lakemond, C. M. M., Ottevanger, E., Bosch, G., and Boekel, M. A. J. S. Van. 2012. Wageningen UR Livestock Research Partner In Livestock Innovations Insects As A Sustainable Feed Ingredient In Pig And Poultry Diets -A Feasibility Study Title Insects As A Sustainable Feed Ingredient In Pig And Poultry Diets -A Feasibility Study. (October). Retrieved From Http://Www.Livestockresearch.Wur.N1

Zainuddin, Safrida, dan Iskandar, E. 2016. Analisis Faktor-Faktor Yang Berhubungan Dengan Motivasi Petani Dalam Faktor Yang Berhubungan Dengan Motivasi Petani Dalam Berusahatani Lada di Kabupaten Aceh Besar. Jurnal Ilmiah Mahasiswa Pertanian Unsyiah, 1: 394-409. 